\title{
OWNERSHIP FORM, MANAGERIAL INCENTIVES, AND THE INTENSITY OF RIVALRY
}

\author{
GOVERT VROOM \\ Purdue University \\ JAVIER GIMENO \\ INSEAD
}

\begin{abstract}
This study investigates how differences in ownership form-between franchised and company-owned units-affect managerial incentives and competitive pricing in different oligopolistic contexts. We argue that chains may restrict decision making in company-owned units as a commitment device to maintain high prices in concentrated markets and found evidence consistent with this argument. We also found that a unit's ownership form affected its rivals' competitive behavior. Our results indicate that company-owned units' ability to raise their own and rivals' prices in highly concentrated markets led to their higher performance relative to franchised units.
\end{abstract}

Over the years, competitive strategy research has examined the dynamics of competitive interaction, including market entry and exit, price rivalry, and other forms of competitive engagement. This research typically depicts firms as unitary actors: it is a firm that makes competitive decisions about the nature and intensity of competitive behavior, with the objective of optimizing firm performance. This view downplays the heterogeneity of internal organization within firms. In most organizations, competitive decisions are delegated to managers whose incentives may be imperfectly aligned with the interests of the organization as a whole. In some situations, firms may even delegate competitive decisions to external independent agents, dealers or franchisees, while their competitors delegate these same decisions to managers inside the firm. For example, with the growth of multiunit and multidivisional organizations in many sectors of the economy, units operated by owner-managers may

The authors would like to thank Jonghoon Bae, Marjolein Bloemhof, Marco Ceccagnoli, Olivier Chatain, Karel Cool, Yves Doz, Arturs Kalnins, Brian McCann, Francisco Ruiz-Aliseda, Vicente Salas Fumás, Metin Sengul, Xavier Vives, Michael Yaziji, Peter Zemsky, participants at the SMS, AOM, CCC, and Harvard Strategy conferences, and seminar participants at HEC, the University of Amsterdam, Erasmus University, and Tilburg University for their helpful comments. We also appreciate the help of Source Strategies, Inc., and the Texas Comptroller's Office for their support with data-related issues. We would like to thank Associate Editor Amy Hillman and the three anonymous reviewers for their valuable feedback and suggestions, which helped improve the article significantly. compete head-to-head with units operated by professional managers of multiunit organizations. Unfortunately, competitive strategy research has not sufficiently explored the competitive interaction among firms with diverse organizational forms.

Delegation of competitive decisions requires parallel consideration of the design of incentive and control systems. Incentive and control systems determine which decisions or tasks are delegated, the limits of the delegated authority, and the explicit and implicit incentives for decision makers. Inside an organization, managerial incentives may be shaped by compensation schemes, expectations of career progression, span of control, administrative rules, organizational structure and culture, and other organizational characteristics. ${ }^{1}$ Differences in incentive systems among organizations may lead to different competitive behaviors and may affect the outcomes of competitive interactions. For example, managers who receive incentives based on market share objectives may act more aggressively in their market than those with strict financial goals (Gupta \& Govindarajan, 1984). Managers may be rewarded for adhering to a corporate pricing policy or encouraged to adapt prices to local market conditions. Managers with incentives based on unit performance rather than firm-level performance may be more willing to engage in competitive actions that

\footnotetext{
${ }^{1}$ As used here, "managerial incentives" rests on the assumption that managers make economically rational decisions that maximize their payoffs. These incentives thus include, but are not limited to, incentive or bonus plans.
} 
cannibalize other revenue sources of their firm (Chandy \& Tellis, 1998; Christensen, 1997). When competitive decisions are delegated to external agents, like franchisees or dealers, the explicit and implicit incentives in the relationship determine the influence of a firm over these external agents. Since external agents are residual claimants, they have discretion over all actions not explicitly contracted with the firm and strong incentives to focus on their own performance.

Some organizational theories, such as the transaction cost economics, agency, organizational ecology, and contingency theories, have examined the outcomes of competition among organizational forms. Usually proponents of these theories propose adaptation and selection mechanisms whereby more efficient organizational forms are selected by an environment. Yet often these theories have glossed over how organizational forms interact in oligopolistic competitive contexts. The argument has been that competitive selection is determined by "economizing" rather than "strategizing” (Williamson, 1991). When the intensity of rivalry is exogenously determined, only superior efficiency determines the competitive success of organizational forms. When organizational forms interact in oligopolistic competitive settings, however, the organizational choices of a firm affect its competitive actions, the intensity of competitive interactions in the market, and, ultimately, its performance outcomes. Consideration of the strategic competitive effects of organizational forms is important for understanding their ultimate performance, yet this dimension has been largely ignored in the existing literature.

This study contributes to the literature by developing a theory of how organizational form can be used as a commitment device to influence competitive interaction. Specifically, we show that chain organizations may use company-owned units as local price leaders, effectively attenuating the intensity of rivalry. Multiunit organizations, ranging from multiunit retail chains to multidivisional or multinational corporations, are important in the U.S. economy (Greve, 2003) and have considerable shares in some industries, such as the restaurant, retail, hotel, and auto service industries (Ingram \& Baum, 1997). Forms of unit ownership may vary over and within these industries. For example, bottlers carry out the local competitive activities of soft drink companies. Some bottlers are fully owned by soft drink companies, others are partially owned by the companies, and still others are independently owned. Multinationals can consist of fully owned units, joint ventures, and units managed by independent foreign agents under contract.
Retail chains may have units that are companyowned and units that are franchised. Here, we focus on this latter case as we examine the effect of the ownership form of hotel units on their competitive behavior in their local markets.

We tested our hypotheses in data on the Texas hotel industry from 1997 to 2002. The panel data allowed us to examine the relationship between ownership forms and competitive behavior over a wide variety of competitive contexts while controlling for alternative explanations and sources of unobserved heterogeneity. A better understanding of the competitive consequences of ownership forms would allow firms to design organizations that are more effective at credibly carrying out their competitive strategy. Moreover, in contrast with the current emphasis on efficient organizational design, our view would allow firms to use ownership forms that effectively balance efficiency and strategic benefits.

\section{THEORY AND HYPOTHESES}

\section{Context}

Multiunit organizations, which have been discussed extensively (e.g., Greve, 2003; Greve \& Baum, 2001; Ingram \& Baum, 1997), are defined as organizations, such as restaurants, hotels, retail chains, and multinationals, that operate in multiple markets through several distinct units. One reason for recently enlarged research interest in these organizations may be the realization of their rapidly growing importance. Ingram and Baum suggested that "chains will eventually come to dominate every service industry that is characterized by some direct contact between customers and organization” (1997: 69). Greve and Baum (2001) pointed out that multiunit organizations are not only prevalent in service industries but are also frequent in the manufacturing sector. Another important reason for a surge in research interest in multiunit organizations is the challenge this organizational form poses for conventional theory. Greve (2003) argued that the multiunit form highlights the shortcomings of theories that are based on the premise of organizations as unitary actors in a unitary environment. Multiunit organizations face an interesting interplay between cross-unit learning and competitive behavior. Moreover, as Greve noted, multiunit organizations have more strategic choices than other organizational forms.

The relevant literature on multiunit organizations can broadly be divided in two groups. The first concerns the question of what the benefits and drawbacks of multiunit organizations are, as com- 
pared with single-unit organizations. In their study of the Manhattan hotel industry, Ingram and Baum (1997) examined benefits and drawbacks of chain affiliation, arguing that chain affiliation improves a local unit's competitive situation by providing resources, reputation, and market power. Ingram (1996) highlighted the tension within multiunit organizations between consistency for the chain as a whole and local adaptation. He suggested that the multiunit organization form could solve the problem of free riding through credible commitment to specified quality levels.

The second stream of research on multiunit organizations is focused on the choice of ownership form within a multiunit organization-that is, the choice between company ownership and franchising of units (e.g., Caves \& Murphy, 1976). This choice is affected by the differential characteristics of these two ownership forms regarding the ability to monitor local managers and the incentive for local managers to free ride on brand-name capital and firm-specific assets (e.g., Bergen, Dutta, \& Walker, 1992; Brickley \& Dark, 1987; Lafontaine, 1992). An argument for the use of franchising is that the relative ease of obtaining franchisee labor and capital facilitates rapid growth for starting firms (e.g., Combs, Michael, \& Castrogiovanni, 2004). In a traditional franchise, the franchisor sells a (semi)finished good to the franchisee; in "business format franchising," on the other hand, the franchisee obtains the right to use the franchisor's trade name and business plan. In the latter case, the franchise contract typically specifies the fees the franchisee should pay, such as an initial fee and royalty and marketing fees.

\section{Ownership Forms and Competitive Behavior}

This article examines how ownership might affect competitive behavior. Ownership confers two property rights: residual control rights and residual income rights (Hart, 1995). Ownership forms, defined as different structures of property rights, thus differ in residual control and income rights. ${ }^{2}$ Ownership may affect competitive behavior to the extent that ownership shapes the incentives of managers who make competitive decisions. Ownership could relate both to vertical relationships (i.e., regarding upstream suppliers and downstream buyers) and horizontal relationships (i.e., regard-

\footnotetext{
2 The term ownership form has been used in the economics and management literatures to represent units with different structures of property rights (e.g., Hansmann, Kessler, \& McClellan, 2003).
}

ing different units supplying similar goods in different local markets or segments). In both cases, one might wonder if competitive behavior differs depending on whether the units are owned separately or jointly.

Economics has studied how vertical ownership forms affect competitive behavior. For example, Spengler (1950) argued that a vertically integrated monopolist will charge a lower price than two vertically adjacent monopolists. The reason is that the downstream monopolist purchases the goods at a margin above cost and thus applies a profit margin on top of the margin at which the goods were purchased. This procedure results in an accumulation of margins referred to as double marginalization. In the absence of competition, double marginalization increases the price for the end consumer to an inefficiently high level. However, double marginalization may also occur in oligopolistic situations in which firms have less-than-perfect market power. There has been ample empirical support for this argument. For example, Muris, Scheffman, and Spiller (1992) found that consumer prices for goods from systems of independent bottlers were higher than the prices of those from integrated soft drink bottlers. ${ }^{3}$

Horizontal ownership may also affect competitive behavior. For example, if demand spillovers are present, managerial incentives may differ depending on whether only one or multiple units are owned (Lafontaine, 1999). Demand spillovers can be illustrated by the following examples: A low price at one unit may increase demand not only for that unit but also for other units that belong to the same chain (positive demand spillover). Conversely, a low price at one unit may cannibalize demand at other closely located units that are perceived as substitutes (negative demand spillover). In the case of independently owned units, the spillover would be treated as an externality, but the spillover would be internalized when the same owner owns both units. In conclusion, both vertical and horizontal ownership may affect the competitive behavior of individual units.

Another theoretical mechanism linking ownership form and competitive behavior that has not yet received sufficient scholarly attention is the effect of ownership form on commitment to particular competitive responses. In other words, we explore the question of whether units with different ownership forms differ in their ability to commit to

\footnotetext{
${ }^{3}$ For a review of the determinants and effects of vertical integration, see Perry (1989).
} 
more or less aggressive competitive behavior. This question is discussed in the next section.

\section{Strategic Commitment through Ownership Form}

In this article, we focus on two prevalent ownership forms used by multiunit organizations: company ownership and franchising. We explore how the differences between these two ownership forms may affect competitive behavior. Although competitive interactions among rivals may happen in multiple dimensions of strategy (e.g., Ferrier, Smith, \& Grimm, 1999), here we specifically study the pricing behavior of these company-owned and franchised units and its effect on competitive pricing by their rivals. Firms compete for customers by giving them superior "value propositions," defined as the maximum price a customer is willing to pay for the product attributes minus the price actually paid. Firms can improve their value propositions by increasing product and service offerings, quality, and other dimensions valued by customers. However, the price the firm sets determines whether the firm or the customer appropriates value. This distinction between value creation and value appropriation highlights the strategic importance of price setting in competitive contexts. A second reason price is an aspect of competition that was particularly well suited for our study is that prices are more adaptable than other dimensions of competition, such as quality or location. This adaptability implies that prices are more responsive to changes in the competitive landscape and thus reflect competitive interaction well.

Franchising and company ownership differ fundamentally on two key dimensions of organizational design that may affect competitive behavior. These key design dimensions relate to the allocation of control rights to units (delegation of authority) and the incentives of unit managers (objectives, control systems, and rewards).

The franchising ownership form contractually endows residual control rights to a local unit, the franchisee. In other words, the franchisee is entitled to decide about all aspects of its business except for those that the contract with the franchisor explicitly delimits. A franchisor or brand owner may impose certain obligations aimed at guaranteeing a consistent level of quality throughout a chain, may specify certain product characteristics, or may engage in nationwide advertising to influence demand. Yet these contractual conditions apply to all units within the chain. Moreover, contracts cannot legally specify prices at the unit level. ${ }^{4}$ Thus, franchisees set their own price (Yin \& Zajac, 2004).

Whereas franchisees have substantial autonomy to set prices, the managers at the corporate headquarters of a chain are free to decide what level of autonomy to give to the managers of local units. A corporate office may let local managers operate relatively freely, so long as they respect the quality standards that define the brand, or they may decide to provide strict rules and guidelines detailing not only operational procedures but also competitive actions such as pricing. Yin and Zajac studied the governance differences between franchising and company ownership and concluded that "companyowned stores are much more hierarchical and are subject to much more control and monitoring from chain operators than franchised stores" (2004: 368). Specifically, they found that "pricing is determined by headquarters for company-owned stores" (2004: 370). ${ }^{5}$

A second difference between franchising and corporate ownership concerns incentive and reward systems. In the case of franchising, after paying various fees to the franchisor, the franchisee is the residual claimant for the remaining income, a situation creating powerful incentives. The payment of franchise fees, typically set as a function of unit revenues, may lead to a distortion of the franchisee's objective function. Because the franchisees bear the full unit costs but only capture a portion of unit revenues, their incentives to cut prices to generate additional volumes and revenues is reduced. In a variety of industrial contexts, this distortion (double marginalization) has led franchised units to set higher prices than company-owned units (see Lafontaine and Slade [1997] for a review of this literature). ${ }^{6}$ By contrast, in company ownership the

\footnotetext{
${ }^{4}$ In the United States, the autonomy of franchisees to set prices is well anchored in legal contexts. See Lafontaine (1999) and Blair and Lafontaine (1999) for more details about the legal background of resale price maintenance in franchising.

${ }^{5}$ A detailed comparative analysis of governance and other differences between company ownership and franchising can be found in Bradach (1998).

6 This effect holds both in the case of traditional franchising, in which the franchisee purchases a (semi)finished good from the franchisor, and in the case of business format franchising, in which the franchisee pays a royalty fee for the use of a trademark. In the latter case, it is crucial to note that royalty fees are typically a percentage of revenues rather than a percentage of profits (Lafontaine \& Shaw, 1999). The payment of a fee that is a percentage of revenues distorts competitive behavior in the same way as double marginalization does, but the
} 
incentive system may vary from case to case. Managers' reward systems are typically based on factors such as revenues, costs, market share, occupancy, and other performance measures. A specific reward system could lead to double marginalization, but there is no reason to expect the general occurrence of double marginalization as in the case of franchising.

Before we explore how the above-described differences in control rights and incentive systems may affect the competitive behavior of companyowned and franchised units, we first analyze the challenges the units of multiunit organizations typically face. These units generally compete in local markets in retail or service industries in which goods are differentiated. Because competition occurs in a limited geographic area, it is oligopolistic, even though the number of local competitors varies. Oligopolistic competition generally drives prices below the monopoly level, which implies that (modest) increases of the average market price would have a positive effect on industry profitability. When oligopolistic competition focuses on the price dimension, firms need to understand that their own and rivals' prices in general move in the same direction: if a focal firm decreases its price, competitors' residual demand decreases, and generally it is in the interests of direct competitors to decrease prices too, while the opposite is true if the focal firm increases its price (Bulow, Geanakoplos, \& Klemperer, 1985). This scenario suggests that playing the role of price leader increases profits for both a firm and its competitors if rivals follow (Fudenberg \& Tirole, 1984). However, rivals only follow a price leader's action if the price commitment is credible (Schelling, 1960). We argue that the organizational differences between franchised and company-owned units affect their ability to act as price leaders. Specifically, although company-owned units can credibly commit to sustaining price discipline in their local market, franchised units find it difficult to do so, as explained below.

The value of commitment as a way of strategically influencing one's competitors has been a crucial topic of research in competitive strategy and game theory (see, for example, Dixit, 1980; Ghemawat, 1991). A commitment that is observable, understandable, and credible limits the action space of an actor, which affects the payoffs of its rivals and, ultimately, the optimality of its rivals' reaction possibilities (Besanko, Dranove, \&

payment of a fee based on profits does not (Schmidt, 1994).
Shanley, 2000). A company-owned unit can credibly commit to increasing its price level because of the administrative constraints created by the delegation relationship between the center and local unit. The manager of a company-owned unit must operate within the rules and guidelines set by corporate headquarters. In other words, a manager of a company-owned unit can credibly commit to setting relatively high prices because corporate headquarters told them to do so. Similarly, Bradach referred to company ownership as "a military model" (1998: 1).

For rules and guidelines in a corporate ownership context to create a credible commitment, they have to be difficult to reverse (Dixit \& Nalebuff, 1991). One may wonder whether administrative directives are indeed fully rigid. In other words, can directives be changed in the face of competition and thus nullify the credibility of the commitment? Chains typically develop pricing policies within which local managers have to operate. Corporate headquarters habitually use annual budgets with detailed information about price levels for different products and the quantity of the output. These budgets are decided upon after some form of internal negotiation with the local units. The obligation to act according to the described administrative system, consisting of a pricing policy and an annual budget, significantly restricts a local manager's autonomy. This restriction cannot easily be changed because of the administrative costs. Moreover, for reputational reasons within a chain, headquarters have an incentive not to renege on these internal contracts. In sum, we conclude that the system of internal control that administers the relationship between headquarters and companyowned units creates managerial incentives that may indeed be difficult to reverse, at least in the short term.

Clearly, franchised units face a completely different situation. A franchisee may want to commit to setting higher prices, yet he or she cannot credibly do so. Pricing decisions are irrevocably the responsibility of the unit. The unit owner can change prices and offer discounts in response to customer and competitive demands. As the residual claimant, the unit owner may be strongly tempted to lower prices and increase sales, especially in situations where fixed costs are high and capacity is not fully utilized. The autonomy of the franchisee and the absence of interference by corporate headquarters undermine the ability to engage in credible price leadership.

Given the limitation on franchisees' ability to credibly commit to refrain from discounting, one may wonder whether franchisors can help franchisees by 
using royalty fees to create a credible commitment. As discussed before, royalty fees increase prices through double marginalization and can thus potentially decrease product-market rivalry. Influencing rivalry through royalty fees, however, is imperfect for the following reason: An optimal price increase reflects local competitive conditions. Specifically, the possibility to increase prices and dampen competition may exist in oligopolistic markets, whereas markets that approach perfect competition do not provide the same opportunity. Although the optimal level of royalty fees is contingent on the local competitive context, royalty fees are relatively invariant and cannot adjust to local competitive circumstances. ${ }^{7}$

In conclusion, two conditions are necessary to effectively create price leadership through the choice of ownership form. The first condition is the ability to commit to a price that constitutes an optimal price leadership position, given specific local competitive conditions. The second condition is that this commitment be credible and not easily reneged upon once units compete. Company ownership provides the possibility of satisfying both conditions, because administrative rules and guidelines can be set taking local competitive circumstances into account and, once set, they bind unit managers. By contrast, franchising satisfies neither of the two conditions.

This perspective on multiunit competition reflects a stream of research in economics referred to as strategic delegation theory. Schelling (1960) discussed the use of delegation of authority to an agent as a means to credibly commit to a certain course of action. He provided the example of a negotiation in which one party sends a delegated agent as opposed to participating personally. By choosing an agent with incentives that lead the agent to behave predictably but differently from the principal, a rational player (the principal) can credibly commit to an action that otherwise would not be credible. Vickers (1985), exploring the implications of the concept of strategic delegation for the theory of the firm, pointed out that though owners typically have profit-maximizing incentives, the managers who populate a firm do not necessarily have such incentives. The presence of delegation in firms can allow

\footnotetext{
${ }^{7}$ Royalty fees are relatively invariant for several reasons. First, franchise contracts have a typical duration of 15 years, and contract terms are very persistent over time (Lafontaine \& Shaw, 1999). Moreover, the typical terms of franchise agreements are public knowledge, which limits the possibility of offering different terms to different franchisees (see, for example, the 2001 Hotel Franchise Fees Analysis Guide, from HVS International).
}

them to benefit from strategic effects that would otherwise not be possible. In sum, Vickers argued that "the separation of ownership and control of a firm may be a good thing for the owners, because non-profit-maximizing managers may earn higher profits than would profit-maximizers" (1985: 139). Fershtman and Judd (1987) and Sklivas (1987) formalized the idea of strategic delegation in gametheoretical models). This article can thus be seen as a further development and empirical test of strategic delegation theory in the context of competition among multiunit organizations. ${ }^{8}$ The next subsections develop hypotheses that explore the effect of strategic commitment and royalty fees on pricing behavior, strategic interaction, and revenues.

We have discussed above two distinct theoretical mechanisms that may create a price differential between company-owned and franchised units: strategic commitment through delegation and double marginalization resulting from royalty fees. These two mechanisms may work in opposite directions, because double marginalization causes franchised units to price higher than companyowned units, but strategic commitment through delegation causes company-owned units to price higher. However, whether franchised units or company-owned units will price higher in any specific situation depends on the combination of both effects. Prior research has observed that prices of company-owned units on average tend to be lower than those of franchised units (Lafontaine \& Slade, 1997) but has not been able to explicitly tie the difference to an underlying causal mechanism. The challenge we faced was to develop hypotheses that explicitly separate these two effects-strategic commitment and double marginalization-so that each could be tested independently. Our strategy was to explore contingencies that make each of the

\footnotetext{
${ }^{8}$ Delegation can be defined as the handing over of a task or a decision, usually from one organizational level to a lower one. The existing strategic delegation literature has focused on delegating decision-making authority to agents that have been given incentives different from the principal's. Under those conditions, the combination of agent's autonomy and distorted incentives provide a commitment device for the principal. For example, Bonnano and Vickers (1988) suggested that commitment could be accomplished by contractually separating a marketing unit and removing the incentive to cut price by using a high royalty fee. In our study, commitment occurs via use of organizational rules that constrain the agent's decision range-such as restricting their authority over price-rather than via modification of incentives.
} 
two mechanisms more salient, allowing us to measure the magnitude of each effect separately.

Effect of strategic delegation on competitive pricing. As discussed above, in the case of oligopolistic competition with differentiated goods, an optimal incentive system encourages local units to keep prices relatively high and refrain from discounting. Providing such an accommodating incentive results in an increased price level for a focal firm and encourages a similar response from direct competitors. The benefit of commitment, however, depends on the extent to which strategic interaction plays a significant role in a given market. As the number of firms in a market increases and market concentration decreases, strategic interaction decreases, and the benefit of strategic commitment dissipates. In a market with a large number of competitors, communication and coordination become more difficult, which decreases the potential gain of commitment (Stigler, 1964). In the extreme case of perfect competition, there would be no strategic interdependence, and firms would not set incentives that induce accommodation. Thus, any price premium resulting from strategic delegation should increase as a market becomes more concentrated.

The ability to credibly commit to increasing prices allows chains with company-owned units to benefit from strategic delegation when that would pay off most: in highly concentrated markets. Conversely, because of the full autonomy of franchised units regarding their pricing behavior, these units cannot credibly commit to setting high prices. The difference in the governance mechanism between franchised and company-owned units leads to the following hypothesis:

Hypothesis 1. Market concentration has a stronger positive effect on company-owned units' prices than on franchised units' prices.

Effect of royalty fees on competitive pricing. Because of double marginalization, royalty fees provide the incentive to franchisees to increase the price charged to the end customer. Schmidt (1994) showed theoretically that this distortion directly depends on the magnitude of royalty fees. Although prior research has shown that prices charged by franchised units are on average higher than those charged by company-owned units (Lafontaine \& Slade, 1997), no study, to our knowledge, has evaluated the magnitude of such a price difference and its relation with royalty fees.

Hypothesis 2a. The price charged by franchised units is positively associated with the rate of the royalty fees these units pay, exhibiting a "pass-through effect."
The ability to accumulate margins, however, depends on the competitive context. In the extreme case of perfect competition in a final market, in which no individual firm has any market power, the market price is given and the cost structure may affect survival chances but not pricing behavior. Tirole (1988) posited that the markup would be zero in the case of perfect competition and maximal in the case of monopoly. The extent to which franchised firms can pass through royalty fees to customers thus critically depends on the competitive context. ${ }^{9}$ This argument leads to the following hypothesis:

Hypothesis 2b. The pass-through of royalty fees in a retail price is positively associated with market concentration.

Effect of ownership form on competitive interaction. Hypothesis 1 states that company-owned units increase prices more than franchised units as concentration increases. The underlying argument was that it is favorable for any firm to increase prices, but only company-owned units are capable of credibly committing to doing so. However, increasing price is only favorable if rivals follow by increasing their prices too. The direct effect of a price increase is a quantity decrease, so the effect on revenues, and ultimately profits, is ambiguous. The indirect or strategic effect of a price increase, by contrast, is that rivals increase their price too (Bulow et al., 1985), which increases a focal firm's demand and, thus, its revenues. Consequently, we expect being in direct competition with companyowned units in a concentrated market to increase a unit's price, which leads to the following hypothesis:

Hypothesis 3. Market concentration has a stronger positive effect on prices of the company-owned units' rivals than on prices of the franchised units' rivals.

Effect of ownership form on performance. In the absence of cost information, management scholars and industry practitioners frequently use revenues per unit of capacity as a performance measure, especially in industries with high fixed costs, such as the airline and hotel industries (e.g., Canina, Enz, \& Harrison, 2005). In this study, we

\footnotetext{
${ }^{9}$ Note that royalty fees are not the same for all market participants; independent and company-owned units do not pay royalty fees, and the level of royalty fees differs per brand. Although industry-wide cost fluctuations may be passed through to customers even in the case of perfect competition, firm-specific costs would not be.
} 
followed that practice. Hypothesis 1 asserts that company-owned units set higher prices than franchised units in concentrated markets. In line with this, Hypothesis 3 argues that in concentrated markets company-owned units' rivals set relatively high prices. Hypotheses 1 and 3 taken together suggest that company-owned units play the role of local price leaders, that rivals follow their price increases, and thus that company-owned units effectively lessen rivalry, thus raising performance. This argument leads to the following hypothesis:

Hypothesis 4. As market concentration increases, the revenues per unit of capacity of company-owned units increase more than those of franchised units.

\section{METHODS}

\section{Sample}

The empirical setting of this study was the hotel industry, which is characterized by local competition: hotels compete directly with establishments located in their same area but not with hotels located in a completely different part of their country or state (Baum \& Mezias, 1992). Hotels compete on location choice, quality, range of product offerings, and, after these are determined, price. This study focused on price, which reflects the short-run competitive interaction between hotel establishments. As discussed in the previous section, price constitutes an important aspect of competition, highlighting the difference between value creation and appropriation, and prices are well suited to this study's aims because they are more responsive to changes in the competitive landscape and thus reflect short-run competitive interaction well. Moreover, prices are easily quantifiable, which facilitates statistical analysis, and are accessible to researchers. Finally, the relatively sticky nature of other factors that influence pricing, such as the quality of product offerings, allows for effective control when using panel data.

Several studies have examined the benefits and drawbacks of horizontal ownership forms within chain organizations in the hotel industry. For example, Ingram and Baum (1997), Chung and Kalnins (2001), and Canina, Enz, and Harrison (2005) explored agglomeration spillovers in hotel chains. Ingram (1996) argued that chain organization can solve the problem of commitment to quality. Other studies have explored the difference in behavior between company-owned and franchised units, particularly focusing on the internalization of competitive spillovers within a chain. Conlin (2002), for example, showed that within a given chain, competition between franchised units is fiercer than it is between company-owned units, because franchisees do not consider how their pricing behavior affects demand for other units. In a study of intrachain competition, Kalnins (2004) showed that the entry of franchised units into a market decreases the revenues of the incumbent hotels of the same chain, but the entry of companyowned units increases revenues of incumbents. These studies, however, do not explore the effect of ownership form on pricing across different chains.

The data we used were from the Texas hotel industry. Because of the large size of the Texas market, the heterogeneity of the state in terms of rural and urban regions, and the availability of reliable data, the Texas hotel market is well suited for empirical research. The two primary sources of data we used are a hotel tax file we obtained from the State of Texas Comptroller's Office and the Source Strategy, Inc., database. Chung and Kalnins (2001), among others, used the Comptroller's database, and Conlin and Kadiyali (2006) and Conlin (2002) used the Source Strategy database.

All hotels in Texas are required to report revenues quarterly to the State of Texas Comptroller's Office, which makes these data publicly available. This data set included the hotel name, the location of the hotel, the name and address of the owner, the number of rooms available, and the quarterly revenues. The Source Strategy, Inc., database reported with the same periodicity and included the same hotels, except those with room revenues below $\$ 16,000$ per quarter. The data comprised the name of the hotel, the brand name if the hotel belonged to a chain, its location (town and zip code), the average quarterly occupancy rate, price, and revenue per available room. ${ }^{10}$ The complete data set, which spanned 24 quarters (1997-2002) and contained 76,906 observations, provided unique research opportunities because it contained fine-grained longitudinal competition data as well as detailed data at the establishment level.

Our baseline specification defined the local market as the zip code area in which a focal hotel is situated, in line with Chung and Kalnins (2001). An alternative, firm-centric market definition based on distance to a focal unit was used for robustness checks and is discussed in the Discussion and

\footnotetext{
${ }^{10}$ The average room price (average daily rate), the occupancy rate, and the average revenue per available room are the three most commonly used performance indicators in the hotel industry. The relationship between these three measures is as follows: revenue per available room $=$ occupancy $\times$ average room price.
} 
Conclusion section. In Texas, approximately 3,500 hotel establishments compete in more than 800 local markets. During the period of our sample, 1997-2002, the number of hotels in Texas grew by 5 percent annually. Franchising grew from 30 to 34 percent by the end of 2002. The number of company-owned units grew slightly, from 13 to 15 percent. Independent hotels formed 57 percent in 1997 and 51 percent in 2002. The number of hotels per zip code in our sample ranged from 1 to 54. The number of markets in which only one establishment operated (monopoly markets) equaled 31 percent. In 61 percent of the markets, between 2 and 10 hotels operated. In 8 percent of the markets, more than 10 properties were present.

Although our measures of market characteristics, such as average occupancy rate and market concentration, included all hotels in the market, the regressions only included observations of branded chains (independent hotels were excluded), reducing our sample to 36,668 observations. Comparing chains, consisting of company-owned and franchised hotels, with independent hotels is difficult because of the importance of the brand reputations that the chains have built. Moreover, the data on quality available for chains were not available for independent hotels, which would have made it even more difficult to compare chains with independents. ${ }^{11}$

We used brand dummies rather than segment dummies because within-segment, across-brand differences are significant in the hotel industry. For example, a large business hotel such as the Westin is in many respects different from a niche hotel such as the Four Seasons, even if both are in the luxury segment. Each brand belongs to only one segment.

Some brands chose to have only company-owned or franchised units. In these cases, it was impossible to distinguish between the brand effect and the ownership effect. Of the 82 hotel brands that were in business in Texas, 28 brands operated both franchised and company-owned hotels. We defined a brand as belonging to this category if at least 5 percent of its units were franchised and at least 5 percent were company-owned. Limiting our analysis to brands that contained both franchised and company-owned units reduced our sample to 12,069 observations. Controlling for brand and lim-

\footnotetext{
${ }^{11}$ Some hotel tour books, such as the one published by the American Automobile Association, report a "star rating," but these cover at the most 15 percent of the hotels in Texas (Chung \& Kalnins, 2001).
}

iting our focus to those that had both franchised and company-owned units allowed us to identify the effect of ownership form within a common brand. Table 1 contains a list of the included brands, including information about the market segment, the average price per room, the percentages company-owned and franchised, the royalty fee, and the number of units in Texas.

We treated the choice of ownership form as exogenous to our model. As discussed in the Theory section, a considerable literature examining the choice of corporate ownership versus franchising explores several theoretical perspectives, including agency theory and imperfect capital and labor markets. Theoretically, it is possible that hotel corporations take the strategic commitment effect of ownership choice and its potential performance consequences, as explored here, into account when making the ownership form decision. However, given the novelty of these ideas and the salience of other theoretical reasons to choose between corporate and franchisee ownership, we do not consider this a significant problem. In the section on control variables, we discuss how we dealt empirically with possible selection effects of ownership form.

\section{Dependent Variables}

Price per room per night. The primary dependent variable was the average price for a hotel room. The relative variability and easy measurability made price an empirically powerful aspect of competition, especially because the panel data set allowed effective control for the relatively sticky, nonquantifiable aspects of competition, such as quality and location. We used the natural logarithm of price, because price followed an approximate lognormal distribution. Given controls for other establishment, brand, and market attributes, lower prices reflect more intense rivalry. The price measure was an average for each hotel establishment for each period. In reality, the price per night in a hotel room usually fluctuates according to the length of the stay, the size of the room, the day of the week, and the season. Because our variable was averaged per three-month period, it did not capture these price differences. We do not believe that this data limitation systematically biased our findings.

Rivals' price per room per night. A second dependent variable was the average price the rival hotels in the same market charged. This variable was calculated by dividing the sum of rivals' quarterly revenues in a specific market by the total number of room nights sold by rivals in the same period and market. As described above, we used 
TABLE 1

Brands Operating Both Franchised and Company-Owned Hotels in Texas

\begin{tabular}{|c|c|c|c|c|c|c|c|}
\hline Segment and Brand & $\begin{array}{c}\text { Average } \\
\text { Price in } \\
\text { U.S. Dollars }\end{array}$ & $\begin{array}{c}\text { Occupancy } \\
\text { Rate }\end{array}$ & $\begin{array}{c}\text { Room } \\
\text { Capacity }\end{array}$ & $\begin{array}{c}\text { Royalty } \\
\text { Fee }\end{array}$ & $\begin{array}{c}\text { Percent } \\
\text { Franchised }\end{array}$ & $\begin{array}{l}\text { Percent } \\
\text { Company- } \\
\text { Owned }\end{array}$ & $\begin{array}{c}\text { Number of } \\
\text { Hotels }\end{array}$ \\
\hline \multicolumn{8}{|l|}{ Economy } \\
\hline Country Hearth Inn & 50.55 & $55.4 \%$ & 42 & $4.00 \%$ & $28 \%$ & $72 \%$ & 8 \\
\hline Motel 6 & 36.95 & 64.7 & 110 & 4.00 & 14 & 86 & 95 \\
\hline Red Roof Inns & 44.62 & 60.1 & 129 & 4.48 & 24 & 76 & 28 \\
\hline Shoney's Inns \& Suites & 50.56 & 55.0 & 98 & 3.50 & 33 & 67 & 7 \\
\hline Studio 6 & 35.69 & 66.3 & 131 & 5.00 & 17 & 83 & 6 \\
\hline \multicolumn{8}{|c|}{ Midscale without food and beverage } \\
\hline Baymont Inns \& Suites & 49.58 & 57.2 & 105 & 5.00 & 21 & 79 & 10 \\
\hline Candlewood Hotels & 59.52 & 63.5 & 121 & 4.75 & 13 & 87 & 11 \\
\hline Hampton Inns \& Suites & 66.68 & 66.0 & 105 & 4.00 & 91 & 9 & 61 \\
\hline Mainstay Suites & 61.59 & 55.0 & 80 & 4.50 & 72 & 28 & 4 \\
\hline Sleep Inns & 53.32 & 55.9 & 84 & 4.50 & 60 & 40 & 9 \\
\hline Town Place Suites & 68.66 & 60.1 & 106 & 5.00 & 62 & 38 & 5 \\
\hline Wellesley Inn \& Suites & 53.64 & 56.4 & 124 & 4.50 & 15 & 85 & 7 \\
\hline \multicolumn{8}{|l|}{ Midscale with food and beverage } \\
\hline Club Hotel by Doubletree & 72.41 & 59.0 & 190 & 3.88 & 61 & 39 & 4 \\
\hline Harvey Hotels & 82.33 & 61.2 & 314 & 4.52 & 31 & 69 & 5 \\
\hline Holiday Inn & 68.58 & 61.2 & 214 & 5.04 & 83 & 17 & 78 \\
\hline \multicolumn{8}{|l|}{ Upscale } \\
\hline AmeriSuites & 76.82 & 63.3 & 127 & 5.00 & 22 & 78 & 15 \\
\hline Courtyard by Marriott & 87.86 & 70.0 & 137 & 5.42 & 58 & 42 & 37 \\
\hline Crowne Plaza Hotels & 76.85 & 62.4 & 278 & 5.00 & 37 & 63 & 6 \\
\hline Homewood Suites by Hilton & 100.53 & 65.5 & 103 & 4.00 & 69 & 31 & 16 \\
\hline Radisson & 79.72 & 59.2 & 272 & 4.00 & 87 & 13 & 14 \\
\hline Residence Inn by Marriott & 98.95 & 72.6 & 110 & 4.96 & 59 & 41 & 29 \\
\hline Staybridge & 88.48 & 60.2 & 111 & 5.00 & 20 & 80 & 3 \\
\hline Wyndham Hotels \& Resorts & 110.05 & 61.0 & 404 & 5.00 & 36 & 65 & 8 \\
\hline \multicolumn{8}{|l|}{ Upper upscale } \\
\hline Doubletree Suites & 131.99 & 73.0 & 269 & 3.94 & 54 & 46 & 2 \\
\hline Doubletree & 108.02 & 67.7 & 374 & 3.94 & 86 & 14 & 6 \\
\hline Embassy Suites & 113.12 & 69.2 & 224 & 4.00 & 45 & 55 & 16 \\
\hline Omni Hotels & 112.87 & 64.0 & 363 & 3.00 & 11 & 89 & 9 \\
\hline Sheraton Hotels/Inn/Resorts & 97.01 & 61.6 & 308 & 5.00 & 73 & 27 & 10 \\
\hline
\end{tabular}

both a zip code and a firm-centric market definition.

Revenues per available room. Revenues per available room (typically abbreviated as "RevPAR" by industry practitioners) was used as our performance measure. We calculated this variable by dividing the total quarterly revenues by the number of rooms that were available at a focal hotel.

\section{Independent Variables}

Ownership form. The main independent variable was ownership form. We created a dummy variable for franchised establishments (1, "franchised," 0, "not franchised"). The company-owned ownership form was the omitted variable. We determined whether a unit was franchised or compa- ny-owned in a certain quarter using the brand name, the owner address, and information from the Directory of Hotel \& Lodging Companies (2003). ${ }^{12,13}$

${ }^{12}$ The Directory of Hotel \& Lodging Companies provides the addresses (town and state) of corporate headquarters. All hotels located in the same town as their owners are assumed to be company-owned. All other chain hotels are assumed to be franchised.

${ }^{13}$ Some hotels are "under management contract," which can be considered a separate ownership form. In the case of management contracts, an outside investor group typically owns the hotel and outsources its management to a franchisor. We treated hotels in this category as if they were company-owned because "the managers of these hotels ... f face the same incentive problems 
Market concentration. The most commonly used measure of market concentration is the Herfindahl index, which is defined as the sum of the squared shares of the firms in a given market. We calculated the Herfindahl index on the basis of the capacity share (number of rooms available) of all firms in a market. ${ }^{14}$

Royalty fees. Hotel \& Motel Magazine annually published a "Franchising Supplement" over the 1997-2002 study period, with detailed information about the franchising fees per brand. Our variable indicated the royalty fee per brand as a percentage of revenues. Franchise fees were relatively stable during the period of observation (Lafontaine \& Shaw, 1999). Moreover, changes in the fees were reflected only in the new contracts that were signed after the changes took place. We therefore included average franchise fees per brand over the six-year time period.

Control variables. Because our data were a panel of multiple hotel establishments from multiple chains observed in multiple markets at multiple periods, we used fixed effects to control for sources of heterogeneity that we could not explicitly measure. These fixed effects also account for possible nonindependence of observations that share the same sources of variance. First, we included dummy variables for each period (year and quarter) to control for unobserved seasonal and macroeconomic trends in the Texas economy. Second, we included fixed-effect dummies for the brands in the sample. These dummies controlled for the average quality, reputation, and hotel profile of hotels within a given brand. ${ }^{15}$ Our use of brand dummies provided a superior control for unobserved differences than previously used quality segment dummies. Brand dummies also control for possible nonindependence of observations resulting from coordinated pricing strategies within brands. The brand dummy was based on the brand name for each establishment/period combination as reported in the Strategy Source Inc. database. We crosschecked the brand code with the hotel name reported by the Comptroller's Office. Finally, we included fixed-effect dummies for each physical

that are encountered by the managers of company-owned units" (Kehoe, 1996: 1486).

${ }^{14}$ We used the log of the number of hotels in the market as an alternative measure of market concentration to test for robustness. This alternative definition yielded qualitatively very similar results.

${ }^{15}$ Since hotel corporations typically own multiple brands, the brand dummies distinguish among such different brands owned by a single corporation. establishment. These dummies accounted for the differences in hotel location and stable hotel characteristics, such as hotel size and the quality of the infrastructure.

Establishment dummies were also helpful to account for potential endogeneity of ownership form. It is possible that chains base ownership form choices on characteristics of an establishment or location. If that is the case, estimates of ownership form might suffer from self-selection bias (Hamilton \& Nickerson, 2003), in that unobservable characteristics relevant in the choice of ownership form also influenced the competitive behavior of the establishment. Statistically, that bias would be reflected by a correlation between unobservable establishment characteristics and the ownership form variable. The self-selection problem can be addressed by examining the Hausman test associated with fixed establishment effects because the Hausman statistic explicitly tests whether observed variables are correlated with unobserved sources of heterogeneity.

In addition to the above fixed effects, we controlled for time-varying conditions of supply and demand affecting each particular establishment. To control for supply variations, we included the logarithm of market capacity, defined as the total number of rooms of all establishments in a market. To control for market-specific demand shocks, we included the mean occupancy rate in a local market, defined as the percentage of occupied rooms in the establishments in the market, excluding the focal firm. This exclusion was necessary to avoid potential endogeneity because the firm's own occupancy might be influenced by its price.

\section{Estimation}

Our primary model, a reduced-form price equation for each establishment, was estimated using a panel regression. The functional form can be written as:

$$
\begin{aligned}
\log (\text { price })_{i t} & = \\
& X_{i t} \times \beta+Z_{i t} \times \gamma+\alpha_{i}+\theta_{c(i)}+\tau_{t}+\varepsilon_{i t},
\end{aligned}
$$

where $X_{i t}$ represents the independent variables of interest; $Z_{i t}$, the control variables; $\alpha_{i}$, the establishment fixed effects; $\theta_{c(i)}$, the brand effects; and $\tau_{t}$, the period effects. Apart from the above-described model, we also used the log of rivals' price and revenues per available room as dependent vari- 
ables. The functional form was the same as for the price equation. ${ }^{16}$

\section{RESULTS}

The final sample constituted an unbalanced panel of 630 establishments (either companyowned or franchised) in 260 markets observed over a maximum of 24 periods, totaling 12,069 observations. There were 6,106 observations of franchised hotels and 5,963 observations of company-owned hotels. We compared the variables for these groups using univariate $t$-tests between the two groups. The univariate comparisons showed that franchised hotels tended to have higher prices and revenue per available room. Franchised hotels operated in markets with slightly lower average capacity and in markets where their rivals tended to have higher mean occupancy, but the ownership forms did not differ in the average concentration in their markets. Table 2 presents descriptive statistics, including means and both the overall and the within-establishment standard deviations and correlations. The Pearson correlations confirmed that franchised establishments charged higher prices on average. Price was positively correlated with market capacity and market occupancy and negatively correlated with market concentration. However, these bivariate correlations are not particularly indicative of actual causal effects, given the significant correlations between multiple variables and the effects of unobserved heterogeneity.

Table 3 presents the results of our analysis. To avoid multicollinearity between main effects and interaction effects, and to facilitate interpretation, we centered the interacting variables (market concentration and royalty fee) on their respective means (Aiken \& West, 1991). Because ownership form is a policy variable, we were concerned that it would systematically correlate with characteristics of a chain, market, or establishment. Accordingly, before testing our hypotheses, we examined whether the effect of ownership form on pricing behavior was robust to the inclusion of several fixed effects. Models 1, 2, and 3 examine the effect of ownership form on pricing after we controlled for relevant observed and unobserved effects. The effect of franchise form on price was positive and

\footnotetext{
${ }^{16}$ Instead of estimating the three dependent variables separately, we could have used simultaneous equation estimation. However, separate estimation should not yield biased estimates in a recursive system such as the one studied here. We therefore chose to use the simpler approach of separate estimation.
}

significant when we were only controlling for market occupancy, market supply, and period effects. Yet the coefficient turned negative and significant when we controlled for brand fixed effects. This result indicates that some hotel chains that were more prone to franchising were also more likely to charge higher prices at both franchised and company-owned units. Examination of Table 1 corroborates that large chains in the economy segment were more likely to rely on company-owned establishments (e.g., Motel 6, Red Roof Inn, Studio 6), and some large chains in the upscale and luxury segments were more likely to use franchised establishments (e.g., Doubletree, Sheraton).

Model 3 includes fixed effects for establishments, and the relationship between franchise form and pricing remained negative but was only weakly significant. Longitudinal changes in ownership form for a specific establishment were a necessary condition to ensure statistical power for the estimation of ownership effects in the model with establishment fixed effects. Over the six years of observation, 15.8 percent of the establishments in our final sample changed ownership form, which means that they moved from being franchised to being company-owned or vice versa. Therefore, we inferred that the marginal statistical significance was not a consequence of problems of statistical power. The results suggest that the strongly significant negative effects found in model 2 might be a result of unobserved differences between properties. It appears that within a given chain, franchised units were associated with unobserved establishment characteristics (mainly characteristics of a property itself or its surrounding market) that explained their lower prices. Chains might retain as company-owned establishments either the more expensive properties or those properties with the most attractive market locations. Industry executives confirmed this interpretation, reporting that chains prefer to own the larger, more luxurious properties of a brand because of the complexity of managing these properties (see also Yeap, 2006). The rejection of the null hypothesis $(p<.001)$ in the Hausman test for establishment-specific fixed effects confirmed that sources of unobserved heterogeneity were correlated with the observed variables in the model. We interpreted these results as consistent with self-selection in the choice of ownership form. The inclusion of fixed effects and market-level control variables should alleviate any bias that might be due to self-selection resulting from time-invariant unobserved characteristics or time-variant market characteristics (Hamilton \& 


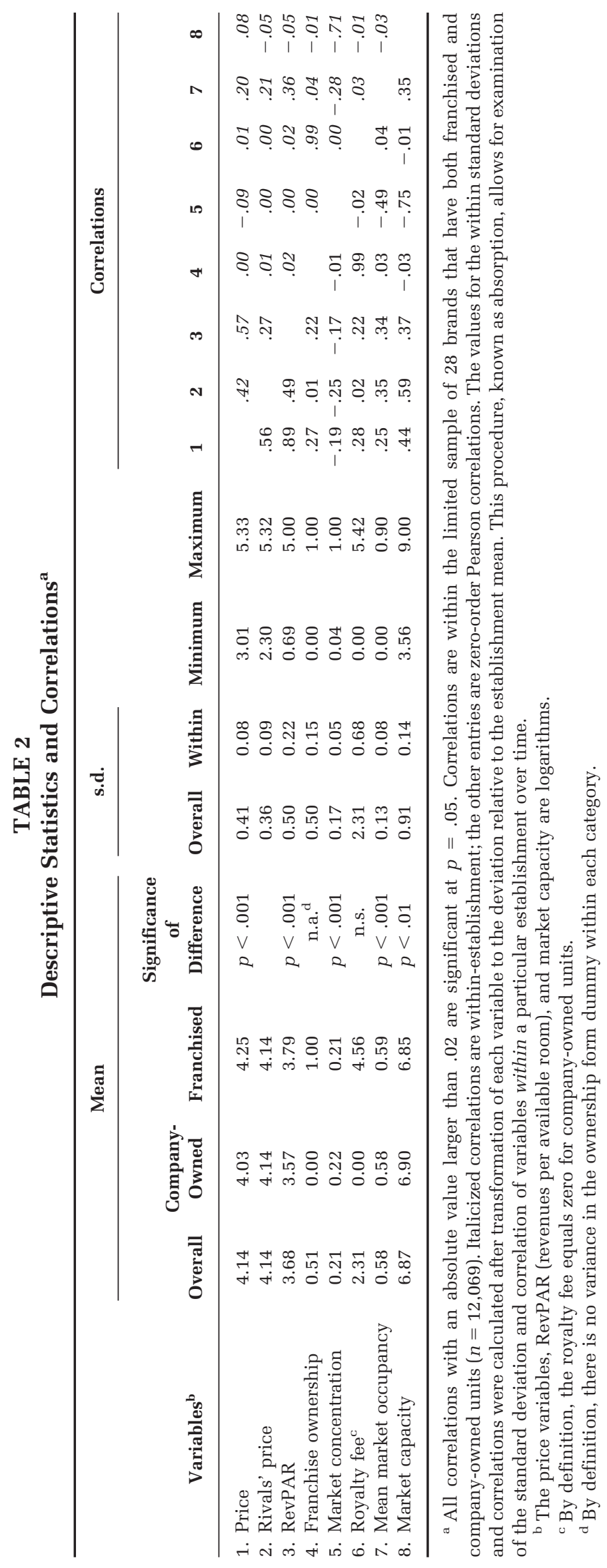




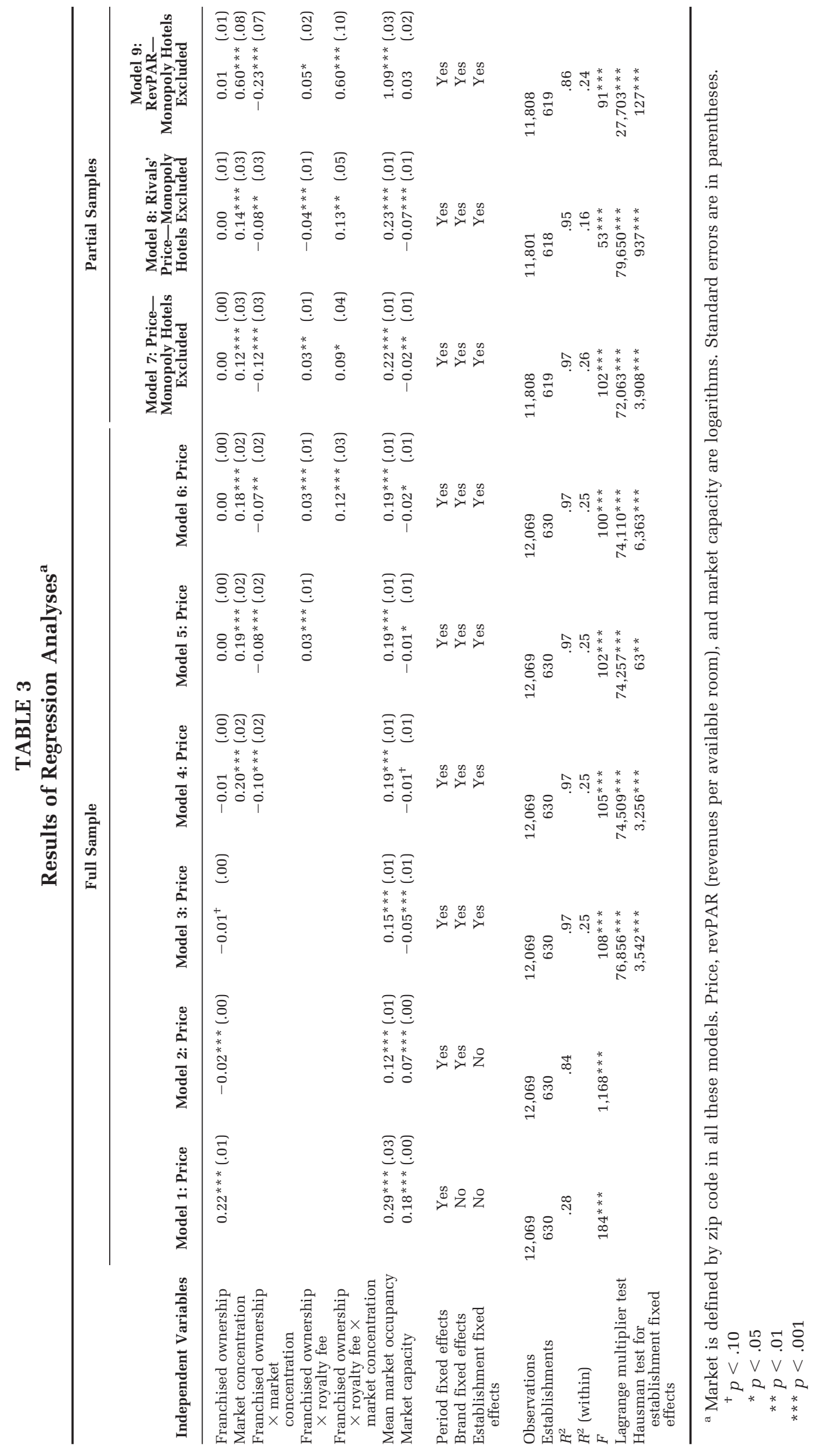


Nickerson, 2003). All subsequent models include period, brand, and establishment fixed effects. ${ }^{17}$

Models 4 to 9 include the tests of the hypotheses. Hypothesis 1 suggests that company-owned units increase their prices more than franchised units when market concentration increases. Model 4 includes the effects of market concentration and the interaction of market concentration with franchise form. Because company-owned properties were the omitted category, the results indicated a positive effect of market concentration on log-prices of company-owned facilities (slope: .20, $p<.001$ ). For franchised units, the effect was determined by the sum of the coefficients (slope: .20 $+(-.10)=.10$, $p<.001)$. The interaction term represented the difference between the concentration-price slopes for company-owned and franchised establishments. The difference is negative and statistically significant $(-.10, p<.001)$, in support of Hypothesis 1 . The evidence suggests that company-owned units were more likely to raise prices than franchised units when market concentration increased and strategic interactions became most salient. ${ }^{18}$ Similar results were obtained when a one-period lagged price was added to the regression as an independent variable. ${ }^{19}$ Figure 1a depicts the relationship between concentration and price for company-owned and franchised units.

Hypothesis 2a suggests that higher royalty fees to franchised units are passed on to customers in the form of higher prices, per double marginalization arguments. Model 5 adds a variable for royalties. The variable was centered on the mean of 4.56 percent for franchised units and was set to 0 for company-owned establishments. The coefficient on the royalty fee was equal to $.03(p<.001)$, which

\footnotetext{
${ }^{17}$ Exclusion of brand effects while keeping the establishment effects yielded very similar results.

${ }^{18}$ In an auxiliary analysis, we identified how changes in concentration and ownership form, respectively, contributed to the results. Clearly, given our fixed-effects model, results would be insignificant without some variation in ownership form and concentration. We carried out two separate analyses, one focused on the effect of concentration changes for establishment that did not change ownership form and another focusing on the effect of ownership changes. These analyses showed that each source of variance was present and contributed to the results in the predicted way.

${ }^{19}$ Because this study does not focus on dynamic adjustment processes, we feel that it is more appropriate to use a traditional regression approach on levels with fixed-effects controls for unobserved heterogeneity rather than to model dynamic changes through the inclusion of a lagged dependent variable (Greve \& Goldeng, 2004).
}

suggests that a one-point increase in royalty is associated with a 3.1 percent increase in the price charged to customers. ${ }^{20}$ The royalty fees ranged from 3 to 5.4 percent in the sample ( 1.56 below the mean to 0.86 above the mean), and the predicted price effects therefore ranged from 4.7 percent below the mean to 2.7 percent above. The results confirm Hypothesis 2a. The insignificance of the franchise dummy suggests that company-owned and franchised units are not found to price significantly differently after the effect of royalty fees and the differential commitment ability are controlled for.

Hypothesis $2 \mathrm{~b}$ suggests that the franchisor's ability to pass on increases of royalty fees to customers is limited in more competitive markets. The positive interaction in model 6 between the royalty fee and market concentration (.11, $p<.001)$ confirms the hypothesis. The sensitivity of prices to royalty fees is plotted in Figure 1b for firms at different concentration levels. As a market becomes more competitive, passing the royalty fee on to customers becomes less feasible. In markets with higher concentration, however, higher royalty fees result in even higher customer prices.

In model 7, we examined whether the differential price effect of company-owned and franchised units was due to monopolistic or oligopolistic pricing. Theory suggests that the credibility of strategic incentives should be particularly important in oligopolistic contexts because in these situations the strategic interaction is most salient. Because of the delegation of pricing to professional managers, company-owned units are able to credibly commit to price leadership, and franchised units are not. Since raising prices in monopoly situations does not involve competitive interactions, it does not require competitive credibility. Consequently, both franchised and company-owned units should be able to raise prices to monopoly levels equally well. Model 7 presents the results for the analysis using a restricted sample that eliminates cases in which an establishment was the only hotel in a zip code market. The predicted slopes of market concentration on the log of price were .12 and .00 for company-owned and franchised units, respectively. With monopoly markets eliminated, the slopes of both ownership forms are smaller than in model 6, as would be expected in view of the restriction of range in the independent variable. However, the difference of the slopes is now greater than in model 6, and the slope of the franchised units be-

\footnotetext{
${ }^{20}$ This percentage is calculated as follows: $\exp (.0313)-1=3.1 \%$.
} 
FIGURE 1

Graphs of Interactions

(1a) Price of Company-Owned and Franchised Units as a Function of Market Concentration

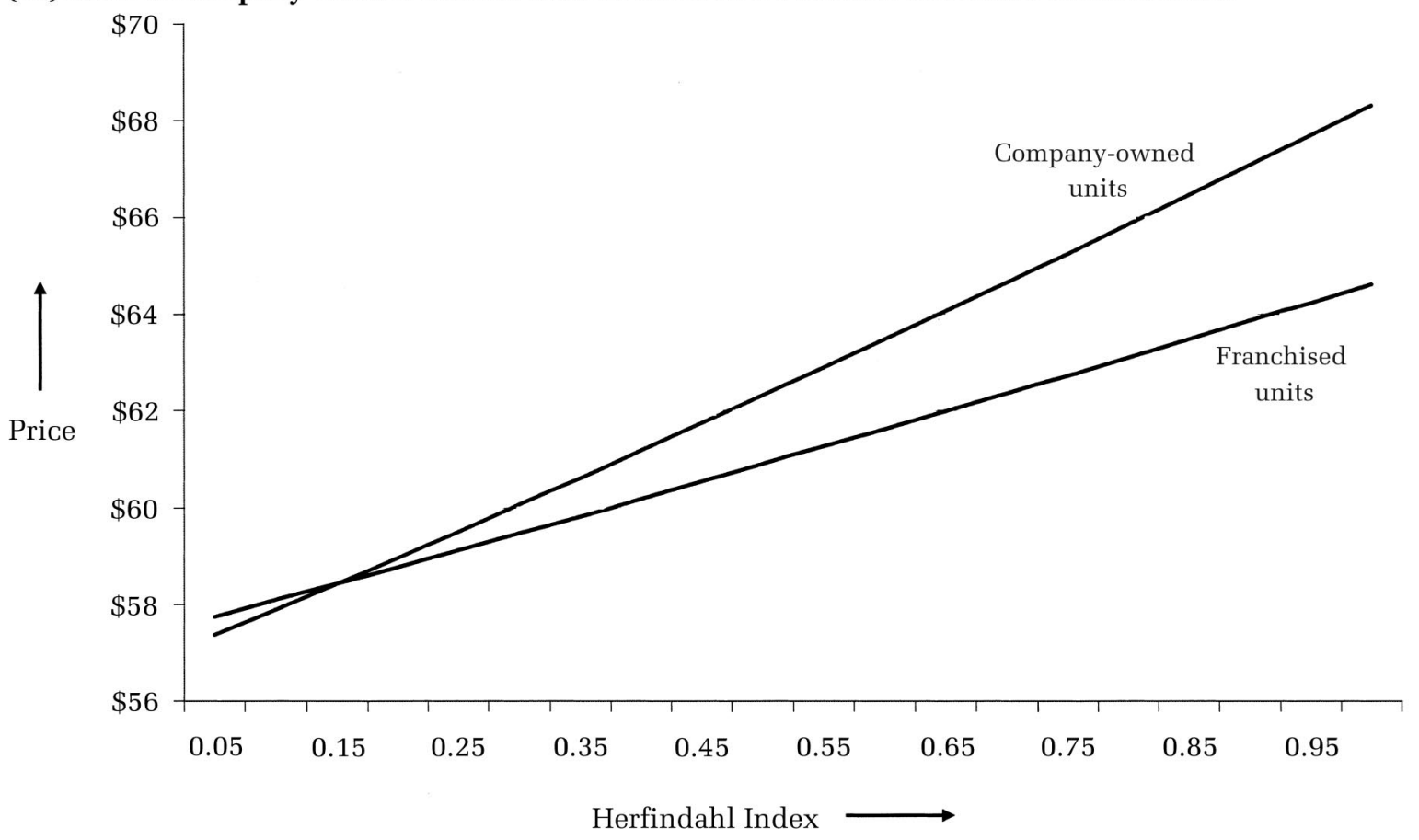

(1b) Price of Franchised Units as a Function of Royalty Fee at Different Levels of Concentration

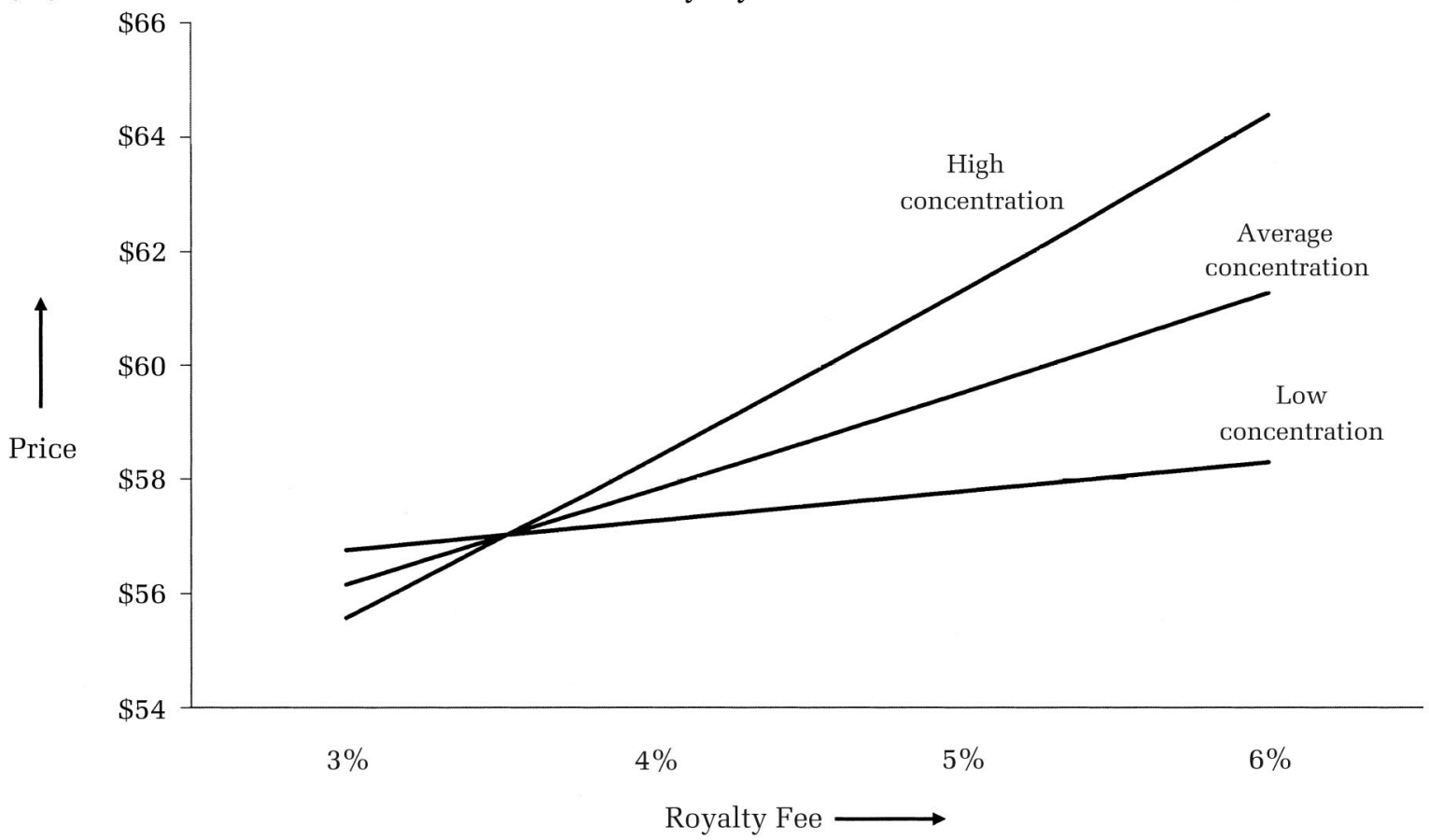

comes insignificant. This result underscores the inability of franchised units to raise prices under oligopolistic conditions.

Hypothesis 3 explores the effect of the ownership form of a focal firm on the pricing behavior of rival firms. In our Theory section, we argue that company-owned units increase prices in concentrated markets because of their intended rivals' reaction: following the price leader. If this reasoning is correct, the rivals of company-owned units would be 
observed to increase prices more than the rivals of franchised units as concentration increases. The results of model 8 confirm this hypothesis because the coefficient of concentration on rivals' prices for franchised units is significantly less than that for company-owned units (.06 versus .14; the difference is significant at the .01 level). These results indicate that the rivals of both company-owned and franchised units increased prices as concentration increased, but the rivals of company-owned units increased their prices more than the rivals of franchised units, as expected.

Finally, Hypothesis 4 discusses the effect of ownership form on performance. Our findings for Hypothesis 1 imply that company-owned units are able to raise prices more than franchised units as concentration increases. This finding, however, does not necessarily imply that company-owned units' performance increase, because the direct effect of a price increase is a trade-off between margin and occupancy volume. However, if a companyowned unit's price increase is followed by price increases by its rivals, as our findings in model 8 suggest, the overall intensity of rivalry will decrease, and the focal firm's performance will increase. This reasoning suggests that revenues of company-owned units increase more than those of franchised units as concentration increases. Model 9 shows the results of an analysis in which revenue per available room is the dependent variable in a sample that excludes monopoly observations. The result indicates that company-owned units obtained higher revenues per available room in more concentrated markets than franchised units, which is consistent with the combination of our two previous findings: not only company-owned units but also their rivals set relatively higher prices as concentration increases. Thus, franchised units to some extent benefited from concentration increases, yet company-owned units were able to benefit more. ${ }^{21}$

\section{DISCUSSION AND CONCLUSION}

Although traditional research in competitive strategy treats each firm as if it consists of a unitary

\footnotetext{
${ }^{21}$ Both company-owned units (as leaders) and franchised units (as followers) may benefit from price leadership in concentrated markets. However, although franchised units in markets with only franchised units do not benefit from price leadership, company-owned units in markets with only company-owned units do benefit. Therefore, we expect that franchised units on the average benefit less from concentration increases than companyowned units.
}

actor, in this study we explore how the organization of a firm affects the way it competes vis-à-vis its competitors. We have developed arguments that link ownership forms with managerial incentives and competitive behavior. The results are generally supportive of our hypotheses. We find that companyowned hotels are better able to adjust their pricing to the competitive conditions surrounding them and may serve as price leaders in more concentrated markets. Strategic delegation theory suggests that such price leadership behavior is effective in encouraging competitors to follow with higher prices. Influencing competitive decision making after delegation to franchisees is more difficult because chains do not have direct control over the end consumer price, as franchisors are prohibited by antitrust regulation from directly influencing franchisees' competitive decisions. Royalty fees could be used to indirectly affect pricing, but franchisors' ability to use royalty fees as a competitive commitment mechanism is shown to be limited because these fees cannot be adjusted to local competitive circumstances.

Market definitions are always to some degree arbitrary, because perfect definition is impossible. We therefore checked the robustness of our findings by trying alternative geographical and product-market definitions. Table 4 presents the results of these robustness checks. First, we investigated the robustness of our geographical market definition by using a distance-based definition of local market instead of the zip code definition. We "geocoded" the address of each hotel using Web-based EZLocate geocoding services. We then defined the relevant market by the establishments within a radius of two miles from the focal unit. The average number of establishments within a two-mile radius market was approximately equal to that within a zip code market. The results with this market definition (model 10) were largely consistent with previous results (model 7). The difference of slope between ownership forms remained significant, with an increased magnitude on the slope of concentration for company-owned units. The royalty fee maintained a significantly positive effect on price, which increased with concentration, as expected. $^{22}$

A second robustness check on the market definition took into account the segment in which hotels

\footnotetext{
${ }^{22}$ The same regression calculated within a five-mile radius rather than a two-mile radius yielded very similar results except for the coefficient on the interaction between royalty fee and concentration, which was positive but insignificant.
} 
TABLE 4

Robustness Checks with Varying Definitions of Market ${ }^{\mathrm{a}}$

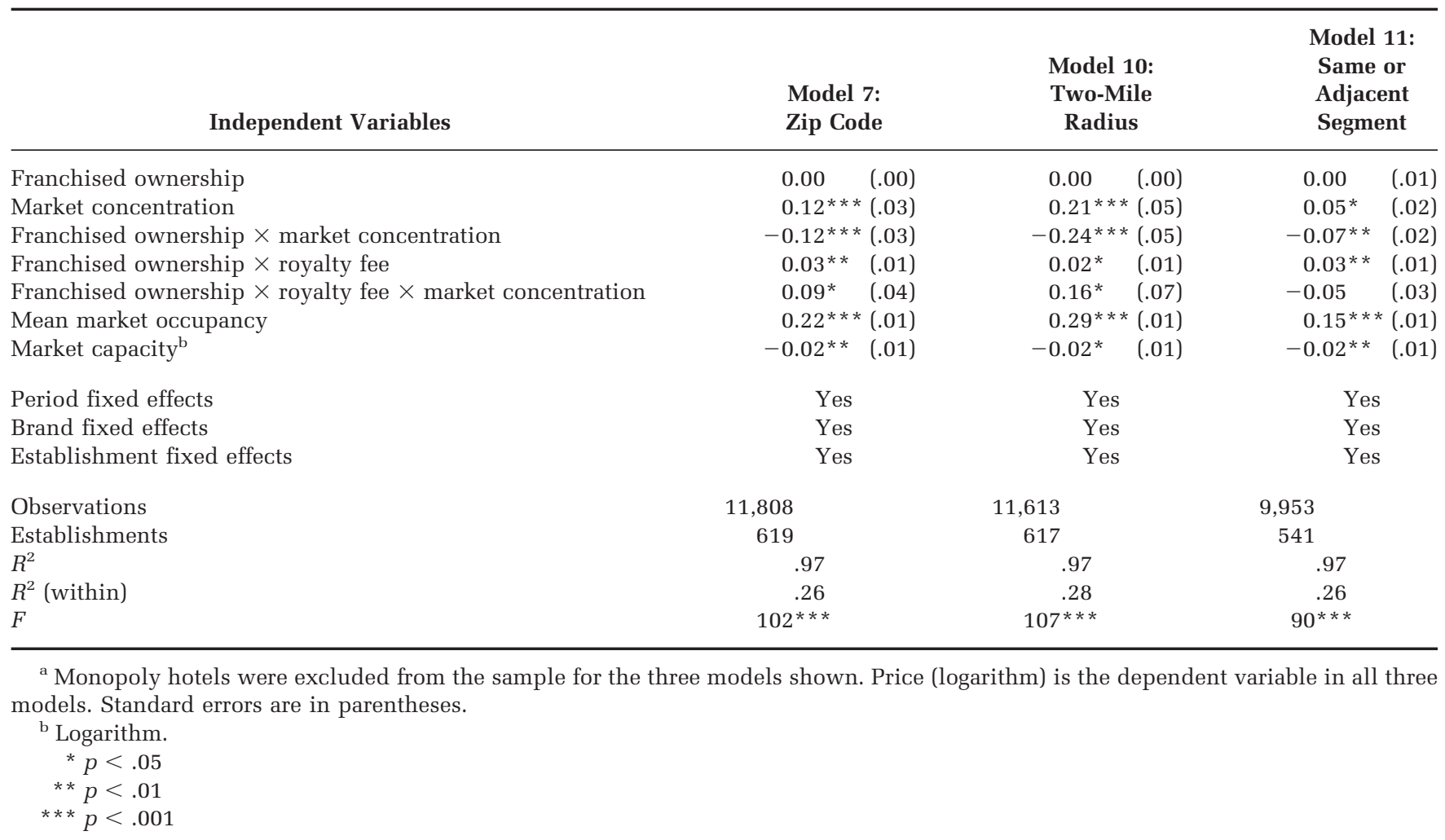

were competing. It might be argued that hotels that are in very different segments do not compete for the same customers. We recalculated market-level variables, such as market concentration and mean occupancy, assuming that hotels only compete with rivals in the same or adjacent segments. The results with this restricted market definition (model 11) are again largely consistent with previous results (model 7). As before, company-owned units were observed to increase price as concentration increased, and franchised units did not. Royalty fees increased room rates, as expected, but this effect did not change depending on the concentration.

In parallel with the quantitative analysis presented above, we conducted interviews with industry participants, such as owner/managers of franchised hotels, managers of company-owned hotels, and top-level and midlevel managers of hotel corporations, to validate our assumptions, reasoning, and conclusions. One topic of these interviews was competition. Most interviewees agreed that competition was a local phenomenon. Hotel managers seemed to know their competitors well. A sales manager of a large company-owned hotel explained, "I know my competitors personally. We send each other overflow customers." We also discussed pricing policies, focusing on the difference between company-owned and franchised units. Pricing policies, practices, and the use of systems such as yield or revenue management varied significantly among the different interviewees. Large, chain-affiliated hotels used yield management systems more than small or independent hotels did. The interviews indicated that corporate headquarters took local demand and competitive conditions into account when putting pricing policies into place. Within the same hotel corporation, it seemed that the local management of upscale brands had more discretion in pricing than the managers of economy brands. Generally, however, local management had limited discretion in price setting. One manager at corporate headquarters clarified: "We are very prudent with giving local management too much pricing discretion. In fact, local management is closely monitored and gets rewarded if it correctly follows the revenue management system's recommendations." In contrast, franchisees had significantly more discretion in setting prices. In the words of a manager at the franchising department of a hotel corporation, "The chain will provide guidelines for the price the franchisee can charge to customers (a range). This 'target' price range depends on things like the brand, location, etc. However, if business is slow, the hotel owner can decide to provide discounts. The franchisee is 
free to do that." These interviews confirmed our argument that the hands of the company-owned unit's manager are tied-creating the possibility of strategic delegation-while franchisees have full discretion and, therefore, commitment to price leadership is unfeasible.

A final topic of our interviews was price leadership and collusion. There was widespread agreement that price increases could lead to higher profits. Although many interviewees agreed that collectively raising prices would increase profits, most did not see this happening in reality. An interviewed sales manager argued, "Collusion and price setting doesn't work. Someone will always renege. There is no commitment." Another interviewee, vice president of a hotel corporation, saw company-owned units as playing a price leadership role in local markets: "After entry, we set a relatively high price and show that the market can bear the higher price. Often, but not always, our competitors pick this up and increase their prices, too." This last statement follows a reasoning that is identical to this paper's main argument: franchised units cannot credibly commit to raising prices in concentrated markets, but company-owned units can increase the average market price through strategic delegation and thus decrease the intensity of rivalry.

It is worthwhile contrasting our findings with those of previous research. Lafontaine and Slade (1997) cited six prior studies showing that franchised outlets charged a higher price than companyowned outlets, which was typically interpreted as evidence of double marginalization. Two studies dealt with gasoline stations (Barron \& Umbeck, 1984; Shepard, 1993), two with fast-food chains (Lafontaine, 1995; Graddy, 1997), one with pubs (Slade, 1998a), and one with soft drink bottlers (Muris et al., 1992). Our results do not refute these findings. Specifically, model 1, controlling for market occupancy, market capacity, and period effects, shows that franchised units on average charge a higher price than company-owned units. However, the cited studies-and model 1-do not distinguish among several causal mechanisms that might underlie this price difference. The price difference between company-owned and franchised units could be a result of double marginalization, unobserved heterogeneity at the establishment level caused by the location or the quality of the product offering, or, as we argue in the Theory section, the different ability to credibly commit to price increases. Our empirical design allowed us to separate these potential explanations. First, we found confirming evidence for double marginalization through the positive relationship between royalty rates and prices of franchised units, making this study the first to quantify the double marginalization effect and to tie it directly to royalty fees and competitive circumstances. Second, after controlling for double marginalization, we found that in more concentrated markets, company-owned units and their direct rivals priced higher than franchised units and achieved a higher performance, providing evidence for commitment via strategic delegation. Finally, our empirical design allowed us to control for the third potential causal mechanism: unobserved heterogeneity at the establishment level.

Theoretical treatment of strategic delegation theory has been ample; empirical evidence supporting this theory has been scant. Two notable exceptions are Slade (1998b) and Aggarwal and Samwick (1999). Slade found that the likelihood of vertical separation in gasoline stations increased as the benefit of separation through strategic delegation increased. Aggarwal and Samwick found, in a cross-sectional study of companies listed on a stock exchange, that the weight placed on rivals in executive compensation schemes decreased as concentration increased. The above findings provide preliminary evidence for strategic delegation theory. In this study, we show that chains may use companyowned units to credibly commit to less aggressive pricing behavior and soften competition in concentrated markets, confirming strategic delegation theory. One way to understand our results is to look at them in light of a metaphor provided by the well-known legend of Ulysses. When, in the course of their years at sea, Ulysses and his sailors approached the Sirens, whose beautiful singing lured ships to run aground on jagged rocks, he ordered them to tie him to the mast of the ship and to put wax in their own ears to avoid being tempted by the Sirens' songs. By doing so, Ulysses managed to steer away from the Sirens and continue his journey. Equivalently, by tying the hands of managers, one may be able to make them resist the short-term temptations of price competition in their market and achieve a more profitable outcome. ${ }^{23}$

The direct generalizability of our findings is limited to industries in which both franchised and company-owned establishments compete in a locally oligopolistic context, which nevertheless includes most retail and service industries (Greve \&

${ }^{23}$ Elster (1979) discussed this example of the idea that individuals can sometimes choose their own constraints in his Ulysses and the Sirens. 
Baum, 2001). Moreover, the effect whereby strategic delegation makes company-owned units behave less aggressively than franchised units is contingent on an industry being based on price competition among differentiated offerings. The hypotheses may not extend to other industry settings in which competition focuses on capacity or investment preemption and where a more aggressive preemptive strategy is appropriate. However, the general finding that the ownership and organizational characteristics of a firm affect competition between firms may be more broadly applicable. This study took firm ownership as one characteristic that affects managerial incentives, focusing on the franchise versus company-owned distinction. Future research could expand this exploration to other ownership typologies, such as government-owned firms, employee cooperatives, family-owned firms, management buyouts, and so forth. Moreover, before one could conclude that in general "the inside matters for competition," future research should study other organizational characteristics, such as compensation schemes and organizational structure, and their effect on interfirm rivalry.

In many industries, companies make decisions about organizational forms and boundaries: for example, whether to own or to use third-party channels, whether to enter markets through joint ventures or acquisitions, or whether to consolidate through alliances or mergers. This study allows companies facing these choices to understand how different organizational arrangements may affect their ability to capture value in the implicit negotiation with rivals and customers. We find that companies that have full control over local units and can implement administrative systems that constrain managerial behavior (company ownership) are better able to commit to price leadership. This finding is not only theoretically important but also practically relevant, because in many cases a company's ability to manage its competitive environment is an important determinant of its performance.

\section{REFERENCES}

Aggarwal, R. K., \& Samwick, A. A. 1999. Executive compensation, strategic competition, and relative performance evaluation: Theory and evidence. Journal of Finance, 54: 1999-2043.

Aiken, L. S., \& West, S. G. 1991. Multiple regression: Testing and interpreting interactions. Newbury Park, CA: Sage.

Barron, J. M., \& Umbeck, J. R. 1984. The effects of different contractual arrangements: The case of retail gas- oline markets. Journal of Law \& Economics, 27: 313-328.

Baum, J. A. C., \& Mezias, S. J. 1992. Localized competition and organizational failure in the Manhattan hotel industry, 1898-1990. Administrative Science Quarterly, 37: 580-604.

Bergen, M., Dutta, S., \& Walker, O. C. 1992. Agency relationships in marketing: A review of the implications and applications of agency and related theories. Journal of Marketing, 56(3): 1-24.

Besanko, D., Dranove, D., \& Shanley, M. 2000. Economics of strategy (2nd ed.). New York: Wiley.

Blair, R. D., Lafontaine, F. 1999. Will Khan foster or hinder franchising? An economic analysis of maximum resale price maintenance. Journal of Public Policy \& Marketing, 18(1): 25-36.

Bonanno, G., \& Vickers, J. 1988. Vertical separation. Journal of Industrial Economics, 36: 257-265.

Bradach, J. L. 1998. Franchise organizations. Boston: Harvard Business School Press.

Brickley, J. A., \& Dark, F. H. 1987. The choice of organizational form: The case of franchising. Journal of Financial Economics, 18: 401-420.

Bulow, J. I., Geanakoplos, J. D., \& Klemperer, P. D. 1985. Multimarket oligopoly: Strategic substitutes and complements. Journal of Political Economy, 93: $488-512$.

Canina, L., Enz, C. A., \& Harrison, J. S. 2005. Agglomeration effects and strategic orientations: Evidence from the U.S. lodging industry. Academy of Management Journal, 48: 565-581.

Caves, R. E., \& Murphy, W. F. 1976. Franchising: Firms, markets, and intangible assets. Southern Economic Journal, 42: 572-586.

Chandy, R. K., \& Tellis, G. J. 1998. Organizing for radical product innovation: The overlooked role of willingness to cannibalize. Journal of Marketing Research, 35: 474-487.

Christensen, C. M. 1997. The innovator's dilemma: When new technologies cause great firms to fail. Boston: Harvard Business School Press.

Chung, W., \& Kalnins, A. 2001. Agglomeration effects and performance: A test of the Texas lodging industry. Strategic Management Journal, 22: 969-988.

Combs, J. G., Michael, S. C., \& Castrogiovanni, G. J. 2004. Franchising: A review and avenues to greater theoretical diversity. Journal of Management, 30: 907932.

Conlin, M. 2002. The effect of franchising on competition: An empirical analysis. Working paper, Syracuse University.

Conlin, M., \& Kadiyali, V. 2006. Entry deterrence capacity in the Texas lodging industry. Journal of Economics and Management Strategy, 15: 167185. 
Directory of Hotel \& Lodging Companies. 2003. Washington, DC: American Hotel \& Lodging Association.

Dixit, A. 1980. The role of investment in entry-deterrence. Economic Journal, 90(March): 95-106.

Dixit, A., \& Nalebuff, B. J. 1991. Thinking strategically: The competitive edge in business, politics, and everyday life. New York: Norton.

Elster, J. 1979. Ulysses and the sirens. Cambridge, U.K.: Cambridge University Press.

Ferrier, W., Smith, K., \& Grimm, C. 1999. The role of competitive action in market share erosion and industry dethronement: A study of industry leaders and challengers. Academy of Management Journal, 42: $372-388$

Fershtman, C., \& Judd, K. L. 1987. Equilibrium incentives in oligopoly. American Economic Review, 77: 927940.

Fudenberg, D., \& Tirole, J. 1984. The fat-cat effect, the puppy-dog ploy, and the lean and hungry look. American Economic Review, 74: 361-366.

Ghemawat, P. 1991. Commitment: The dynamic of strategy. New York: Free Press.

Graddy, K. 1997. Do fast-food chains price discriminate on the race? Journal of Business \& Economic Statistics, 15: 391-401.

Greve, H. R. 2003. Why are there so many multiunit organizations? Strategic Organization, 1: $109-115$.

Greve, H. R., \& Baum, J. A. C. 2001. Introduction: A multiunit, multimarket world. In H. R. Greve \& J. A. C. Baum (Eds.), Advances in strategic management, vol. 18-Multiunit organization and multimarket strategy: 1-28. Greenwich, CT.

Greve, H. R., \& Goldeng, E. 2004. Longitudinal analysis in strategic management. In D. D. Bergh \& D. Ketchen (Eds.), Research methods in strategy and management: 135-163. Amsterdam: Elsevier.

Gupta, A. K., \& Govindarajan, V. 1984. Business unit strategy, managerial characteristics, and business unit effectiveness at strategy implementation. Academy of Management Journal, 27: 25-41.

Hamilton, B. H., \& Nickerson, J. A. 2003. Correcting for endogeneity in strategic management research. Strategic Organization, 1: 51-72.

Hansmann, H., Kessler, D., \& McClellan, M. 2003. Ownership form and trapped capital in the hospital industry. In E. L. Glaeser (Ed.), The governance of not-for-profit organizations: 45-70. Chicago: University of Chicago Press.

Hart, O. 1995. Firms, contracts, and financial structures. Oxford, U.K.: Oxford University Press.

Ingram, P. 1996. Organizational form as a solution to the problem of credible commitment: The evolution of naming strategies among U.S. hotel chains,
1896-1980. Strategic Management Journal, 17: 85-98.

Ingram, P., \& Baum, J. A. C. 1997. Chain affiliation and the failure of Manhattan hotels, 1898-1980. Administrative Science Quarterly, 42: 68-102.

Kalnins, A. 2004. An empirical analysis of territorial encroachment within franchised and companyowned branded chains. Marketing Science, 23: $476-489$.

Kehoe, M. R. 1996. Franchising, agency problems, and the cost of capital. Applied Economics, 28: 14851493.

Lafontaine, F. 1992. Agency theory and franchising: Some empirical results. Rand Journal of Economics, 23: 263-284.

Lafontaine, F. 1995. Pricing decisions in franchised chains: A look at the fast-food industry (Working paper no. 5247). Cambridge, MA: National Bureau of Economic Research.

Lafontaine, F. 1999. Franchising versus corporate ownership: The effect on price dispersion. Journal of Business Venturing, 14: 17-34.

Lafontaine, F., \& Shaw, K. L. 1999. The dynamics of franchise contracting: Evidence from panel data. Journal of Political Economy, 107: 1041-1080.

Lafontaine, F., \& Slade, M. E. 1997. Retail contracting: Theory and practice. Journal of Industrial Economics, 45(1): 1-25.

Muris, T. J., Scheffman, D. T., \& Spiller, P. T. 1992. Strategy and transaction costs: The organization of distribution in the carbonated soft drink industry. Journal of Economics and Management Strategy, 1: 83-128.

Perry, M. K. 1989. Vertical integration: Determinants and effects. In R. Schmalensee \& R. D. Willig (Eds.), Handbook of industrial organization, vol. I: 183255. Amsterdam: Elsevier Science Publishers.

Schelling, T. C. 1960. The strategy of conflict. Cambridge, MA: Harvard University Press.

Schmidt, T. 1994. An analysis of intrabrand competition in the franchise industry. Review of Industrial Organization, 9: 293-310.

Shepard, A. 1993. Contractual form, retail price, and asset characteristics in gasoline retailing. Rand Journal of Economics, 24: 58-77.

Sklivas, S. D. 1987. The strategic choice of managerial incentives. Rand Journal of Economics, 18: 452458.

Slade, M. E. 1998a. Beer and the tie: Did divestiture of brewer-owned public houses lead to higher beer prices? Economic Journal, 108: 565-602.

Slade, M. E. 1998b. Strategic motives for vertical separation: Evidence from retail gasoline markets. Journal of Law, Economics \& Organization, 14: 84-113. 
Spengler, L. 1950. Vertical integration and anti-trust policy. Journal of Political Economy, 58: 347-352.

Stigler, G. J. 1964. A theory of oligopoly. Journal of Political Economy, 72: 44-61.

Tirole, J. 1988. The theory of industrial organization. Cambridge, MA: MIT Press.

Vickers, J. 1985. Delegation and the theory of the firm. Economic Journal, 95(supplement): 138-147.

Williamson, O. E. 1991. Strategizing, economizing, and economic organization. Strategic Management Journal, 12(winter special issue): 75-94.

Yeap, C. A. 2006. Residual claims and incentives in restaurant chains. Working paper, University of Minnesota, Minneapolis.

Yin, X., \& Zajac, E. J. 2004. The strategy/governance structure fit relationship: Theory and evidence in franchising arrangements. Strategic Management Journal, 25: 365-383.
Govert Vroom (vroom@purdue.edu) is an assistant professor of management at the Krannert School of Management, Purdue University. He earned his Ph.D. in management from INSEAD. His research interests include competitive strategy, managerial incentives, organizational design, and industrial organization.

Javier Gimeno (javier.gimeno@insead.edu) is a professor of strategy at INSEAD. He earned his Ph.D. in strategic management from Purdue University. His research interests include competitive strategy, competitive dynamics in multimarket contexts, the effect of organizational incentives and delegation on competitive interaction, and entrepreneurship. 
Copyright of Academy of Management Journal is the property of Academy of Management and its content may not be copied or emailed to multiple sites or posted to a listserv without the copyright holder's express written permission. However, users may print, download, or email articles for individual use. 